\title{
EFFECTS OF CORN CULTIVAR-TILLAGE SYSTEM COMBINATION ON VESICULAR ARBUSCULAR MYCORRHIZAE
}

\author{
Joko Prasetyo ${ }^{1}$
}

\begin{abstract}
ABSTRAK
Pengaruh kombinasi varietas jagung dan sistem olah tanah terhadap mikorisa vesikular arbuskular. Penelitian telah dilakukan untuk mengevaluasi pengaruh kombinasi sistem olah tanah dan varietas terhadap populasi mikorisa vesikular arbuskular. Penelitian juga ditujukan untuk mengetahui pengaruh kombinasi varietas jagung dan sistem olah tanah terhadap infeksi mikorisa vesicular arbuskular. Penelitian terdiri atas enam perlakuan yang disusun dalam rancangan acak kelompok. Perlakuan tersebut adalah varietas RR yang ditanam pada sistem olah tanah konservasi (RRCT), varietas C7 yang ditanam pada sistem olah tanah konservasi (C7CT), varietas Bisma ditanam pada sistem olah tanah konservasi (BCT), varietas RR ditanam pada sistem olah tanah sempurna (RRFT), varietas C7 yang ditanam pada sistem olah tanah sempurna (C7FT), dan varietas Bisma ditanam pada sistem olah tanah sempurna (BFT). Hasil penelitian pada sistem olah tanah konservasi menunjukkan bahwa varietas RR dan C7 secara nyata dapat menurunkan infeksi mikorisa dibandingkan dengan varietas Bisma. Hasil penelitian juga menunjukkan bahwa pada varietas RR dan C7, olah tanah konservasi secara nyata menurunkan infeksi mikorisa dibandingkan dengan sistem olah tanah sempurna.
\end{abstract}

Key words: corn cultivar, tillage, mycorrhizae

\section{INTRODUCTION}

In Indonesia, corn is the most important cereal crops after rice. Corn is grown throughout Indonesia in the zones wherever rainfall or irrigation is adequate. The average corn production in Indonesia, is still lower compared to the other corn producing countries.

Corn production in Indonesia faces many problems. One of the main problems is how to manage weed. So far, the management of weed still needs high cost, particularly for full tillage system. Other than the problem, the implementation of full tillage in the long time results severe soil erosions. Soil erosions degrade soil structure, decrease soil fertility, and reduce the number of soil microorganism, including vesicular-arbuscular mycorrhizal fungi. Allen and Boosalis (1983 cit. Yokom et. al., 1985) showed that mycorrhizal fungi population decreased under fallow rotation compared to grassland. Kruckelmman (1975) showed that tilling by rotary hoe tended to decrease spore number of mycorrhizal fungi.

The herbicide application could decrease the management cost, but there could be negative side effects. Ussually, the herbicide applications cause phytotoxic to plant. Phytotoxicity retards the plant growth and development. Thus, the herbicide must be applied very carefully.

Application of conservation tillage by using herbicide is a rational way of weed management. As mention above, the problem is the phytotoxic effect of the herbicide to the plants. RR-corn cultivar promises to solve this problem. RR-corn cultivar has tolerant character to glyphosate spraying (Kishore et.al., 1992). However, many reports showed that the use of chemical materials to the soil caused negative side effects to vesicular-arbuscular mycorrhizal fungi (Menge, 1982). The present study, therefore conducted in an attempt to evaluate the effect of corn cultivar-tillage combination on mycorrhizal fungi infection and population.

\section{METHODS}

The field experiment was conducted in Natar, South Lampung, from July to September 2001. The experiment was done in the agricultural experimental station of BPTP (Balai Pengkajian Teknologi Pertanian) Natar.

The experiment consisted of six treatments arranged in a completely randomized block design. The treatments were cultivar RR-corn grown under conservation tillage (RRCT), cultivar C7 grown under conservation tillage (C7CT), cultivar Bisma grown

${ }^{1}$ College of Agriculture, University of Lampung Bandar Lampung 
under conservation tillage (BCT), cultivar RR-corn grown under full tillage (RRFT), cultivar C7 grown under full tillage (C7FT), and cultivar Bisma grown under full tillage (BFT). In the full tillage, the land was plowed completely, while in the conservation tillage glyphosate herbicide was sprayed over the plots. The glyphosate was sprayed blangketly over the plots before the seeds sowed, and sprayed between row after the plant emerged from the soil.

Soil and root samples were collected from corn rhizosphere of each experimental unit two months after planting. Soil samples for mycorrhizal fungi population (100 g) were extracted using the method from Daniels and Skipper (1982). The collected spores were counted under microscope in 5 $\mathrm{ml}$ volume. Root samples were stained with lactophenol tryphanblue according to the method of Kormanik dan McGraw (1982) and then mycorrhizal infection was counted according to the method from Giovannetti dan Mosse (1980).

\section{RESULTS AND DISCUSSION}

\section{Mycorrhizal Population}

The results of the experiment (Table 1) showed that cultivar RR-corn grown under conservation tillage significantly decreased mycorrhizal fungi population compared to the other varieties in the same tillage system and Bisma grown in the full tillage. The experiment also showed that cultivar RR-corn and C7 grown in the full tillage system tended to decrease mycorrhizal fungi populatin compared to cultivar Bisma in the same tillage system and cultivar C7 in the conservation tillage system.

The decrease of mycorrhizal population in the experiment could be caused by several factors. The significant decrease of mycorrhizal population of RRcorn grown in the conservation tillage system compared to Bisma in the same tillage system, probably due to the leaves of cultivar RR-corn were more intensively covered soil surface from sunshine. Shading could directly decrease mycorrhizal infection or could indirectly decrease weed population then decrease mycorrhizal population. Weeds are the other host of mycorrhizal fungi other than corn. The decrease of mycorrhizal population in RR-corn grown in the conservation tillage compared to $\mathrm{C} 7$ grown in the same system may be due to the gene which control the dependency of corn to mycorrhizal fungi has lost.

Tabel 1 . The effect of tillage system and cultivar combination on mycorrhizal population

\begin{tabular}{cc}
\hline Tillage System X Cultivar & $\begin{array}{c}\text { Mycorrhizal Population } \\
\text { (Spore Number per g Soil) }\end{array}$ \\
\hline Conservation Tillage & $33.1 \mathrm{~b}$ \\
RR & $59.5 \mathrm{a}$ \\
C7 & $60.6 \mathrm{a}$ \\
Bisma & \\
Full Tillage & $48.0 \mathrm{ab}$ \\
RR & $47.2 \mathrm{ab}$ \\
C7 & $62.6 \mathrm{a}$ \\
Bisma &
\end{tabular}

Notes: Average number in the same column followed by different letters are significantly different (protected LSD, $\alpha=0.05$ )

Genetically cultivar RR-corn and C7 are the same, but the tolerant character to glyphosate inserted in RRcorn. So, it was sure that the decrease was not due to the shading. The decrease of mycorrhizal population in cultivar RR-corn grown in the conservation tillage system compared to cultivar Bisma grown in the full 
tillage system probably also due to the effect of shading .

\section{Mycorrhizal Infection}

The results of the experiment (Table 2) showed that cultivar RR-corn and C7 grown under conservation tillage system significantly decreased mycorrhizal infection compared to cultivar Bisma in the same tillage system. The results of the experiment also showed that cultivar cultivar RR-corn and C7 grown under conservation tillage system significantly decreased mycorrhizal infection compared to cultivar RR-corn and C7 in the full tillage system. There was no difference between cultivar tested in the full tillage system; cultivar Bisma grown under full tillage system tended to decrease mycorrhizal infection compared to cultivar RR-corn, C7 (grown in the full tillage system), and Bisma (grown in the conservation tillage system), but not significantly different.

The decrease of mycorrhizal infection in the experiment may be due to several factors. The decrease of mycorrhizal infection in cultivar RR-corn grown in conservative tillage system compared to Bisma in the same tillage system due to the decrease of mycorrhizal population (Table 1). The decrease of mycorrhizal infection in the cultivar C7 in the conservation tillage system compared to Bisma in the same tillage system was not surely due to the decrease of mycorrhizal population (Table 1), but due to the other reason. The decrease of mycorrhizal infection in cultivar RR-corn and C7 in the conservative tillage system compared to same variety in the full tillage system, probably due to two reasons. First, the decrease was due to the low number of mycorrhizal spores particularly for RR-corn. Second, the decrease was due to the effect of glyphosate.

\section{CONCLUSION}

RRCT significantly decreased mycorrhizal population compared to cultivar C7CT, BCT, and BFT. RRCT and C7CT decreased mycorrhizal infection compared to BCT, RRFT, and C7FT.

\section{ACKNOWLEDGMENT}

I thank to M. Utomo, F.X. Susilo, and I Gede Swibawa for their assistance. This research was funded by Monsanto Corporation.

Table 2. The effects of cultivar-tillage system combination on mycorrhizal infection (\%)

\begin{tabular}{cc}
\hline Tillage System X Cultivar & $\begin{array}{c}\text { Mycorrhizal Infection } \\
(\%)\end{array}$ \\
\hline Conservation tillage & $47.7 \mathrm{~b}$ \\
RR-corn & $44.7 \mathrm{~b}$ \\
C7 & $63.8 \mathrm{a}$ \\
Bisma & \\
Full Tillage & $69.7 \mathrm{a}$ \\
RR-corn & $71.2 \mathrm{a}$ \\
C7 & $57.5 \mathrm{ab}$ \\
Bisma & \\
\hline
\end{tabular}

Notes: Average number in the same column followed by different letters are significantly different (protected LSD, $\alpha=0.05$ ) 


\section{REFERENCES}

Daniels, B.A. \& H.D. Skipper. 1982. Methods for recovery and quantitative estimation of propagules from soil. Pages: 29-36, In Methods and Principles of Mycorrhizal Research. N.C. Schenck (ed.) APS, St. Paul, Minnesota.

Giovannetti, M. \& B. Mosse. 1980. An evaluation of techniques for measuring vesicular arbuscular mycorrhizal infection in roots. New Phytopathol. 18:489-500.

Kishore, G.M., S.R. Padgette, \& R.T. Freley. 1992. History of herbicide tolerant crops, methods of development and current state of the artemphasis on glyphosate tolerance. Weed Tech. 6: 626-634.

Kormanik, P.P. and A.C. McGraw. 1982. Quantification of vesicular-arbuscular mycorrhizae in plant roots. Pages:37-46, In
Methods and Principles of Mycorrhizal Research. N.C. Schenck (ed.) Amer. Phytopathol. Soc., St Paul, Minnesota.

Kruckelmman, H.W. 1975. Effect of fertilizer, soil, soil tillage, and plant species on the frequency of endogone chlamidospores and mycorrhizal infection in arable soil. Pages: 512-525, In Endomycorrhizas. F.E Sanders, B. Mosse, and P.B. Tinkers (Eds.). Academic Press, London.

Menge, J.Y. 1982. Effect of soil fumigants and soil fungicides on vesicular arbuscular mycorrhizal fungi. Phytopathology 72: 1125-1132.

Yocom, D.H., H.J. Larsen \& M.G. Boosalis. 1985. The effect of tillage treatments and fallow seasons on V.A. mycorrhizae of winter wheat. Page: 297, In Procceding of the $6^{\text {th }}$ North American Conference on Mycorrhizae. R. Molina (ed.) Forest Research Laboratory, Bend, Oregon. 
Tabel 1. The effect of tillage system and cultivar combination on mycorrhizal population

\begin{tabular}{|lc}
\hline Tillage System X Cultivar & $\begin{array}{c}\text { Mycorrhizal Population } \\
\text { (Spore Number per g Soil) }\end{array}$ \\
\hline Conservation Tillage & $33.1 \mathrm{~b}$ \\
RR & $59.5 \mathrm{a}$ \\
C7 & $60.6 \mathrm{a}$ \\
Bisma & \\
Full Tillage & $48.0 \mathrm{ab}$ \\
RR & $47.2 \mathrm{ab}$ \\
C7 & $62.6 \mathrm{a}$ \\
Bisma & \\
\hline Notes: average number in the same column followed by different letters are significantly \\
different (protected LSD, $\alpha=0.05$ ). \\
\hline
\end{tabular}

Table 2. The effects of cultivar-tillage system combination on mycorrhizal infection (\%) Tillage System X Cultivar $\quad$ Mycorrhizal Infection

(\%)

\begin{tabular}{cl}
\hline Conservation tillage & \\
\hline RR-corn & $47.7 \mathrm{~b}$ \\
C7 & $44.7 \mathrm{~b}$ \\
Bisma & $63.8 \mathrm{a}$
\end{tabular}

$\underline{\text { Full Tillage }}$

RR-corn $\quad 69.7$ a

$\begin{array}{ll}\text { C7 } & 71.2 \mathrm{a}\end{array}$

Bisma $57.5 \mathrm{ab}$

Notes: average number in the same column followed by different letters are significantly different (protected LSD, $\alpha=0.05$ ). 